\title{
Millimole per Kilogram
}

National Cancer Institute

\section{Source}

National Cancer Institute. Millimole per Kilogram. NCI Thesaurus. Code C68892.

A unit of amount of substance content (molality unit) defined as one thousandth of mole (10E-3 mole) of solute per one kilogram of solvent. 